\title{
Study of Performance of Baby Corn at Different Combination Organic and Inorganic Fertilizers in Mid Hills of Nepal
}

\author{
Subedi S*, KC B, Regmi D, Bhattarai A, Chhetri K and Gnawali A \\ Institute of Agriculture and Animal Science, Nepal \\ Submission: June 13, 2018, Published: August 31, 2018 \\ *Corresponding author: Subedi S, Institute of Agriculture and Animal Science, Lamjung campus, Nepal, Tel: 9847771657; \\ Email: Subedisantosh57@gmail.com
}

Abstract

A field experiment on Baby Corn was conducted at Boudgaun, Sindhupal chowk, Nepal to identify effect of different combination of organic and inorganic fertilizers on yield and yield attributes of baby corn during kharif season of 2017. The experiment was laid out in Randomized Complete Block Design (RCBD) with eight treatments and three replications. The treatments are different combination of vermicompost, farm yard manure and chemical fertilizers. Result revealed that yield and yield attributes are statistically different among treatments. Yield and yield attributing character viz. length and weight of baby corn with and without husk in first three harvest of baby corn were found significantly superior in treatment with $75 \%$ vermi-compost and $25 \%$ inorganic fertilizers. In contrast, root length and plant height of baby corn were found significantly superior in treatment with $75 \% \mathrm{FYM}$ and $25 \%$ chemical fertilizers. The result signifies that performance of yield and yield attributes of baby corn is superior in organic source and best over application of vermicompost.

Keywords: Baby corn; Cob; Farm yard manure; Vermicompost

Abbreviations: RCBD: Randomized Complete Block Design; HPSEC: Humic Derivatives were Assessed by Elemental Analyses Size Exclusion Chromatography; NMR: Nuclear Magnetic Resonance; DOSY: Diffusion Order Spectroscopy

\section{Introduction}

Baby corn (Zea mays L.) is an off shoot of maize which is grown for its young, fresh, finger like green ears, harvested at the time of silk emergence and before pollination and fertilization. It is known as 'Queen of Cereals' [1]. It refers to whole, entirely edible cobs of immature corn harvested just before fertilization at the silk emergence stage [2]. It is rich in phosphorus content $(86 \mathrm{mg} / 100 \mathrm{~g})$ of edible portion in comparison to 21 to $57 \mathrm{mg}$ phosphorus content in other commonly used vegetables [3]. As per the report of EIRI the nutritive value on dry weight basis is:

a. Protein: $15-18 \%$

b. Sugar: $0.016-0.020 \%$

c. Phosphorus: $0.6-0.9 \%$

d. Potassium: 2-3\%

e. Fiber: $3-5 \%$

f. Calcium: $0.3-0.5 \%$

g. Ascorbic acid: 75-80 mg per 100g.
In addition, it is a rich source of thiamine, riboflavin and folic acid and it is an attractive low calories vegetable high in fiber without cholesterol. Baby corn is a nutritious food for the growing population for which its production is to be increased.

In the world it accounts for 8 and 25 per cent of the area and production of cereals, respectively. This venture proved enormously successfully in countries like Thailand, Taiwan, Sri Lanka and Myanmar [4]. The production of baby corn in Nepal is negligible. The production is not even started as baby corn is a very recent development and lacks standard cultivation practice for intensive farming. There is no knowledge of production technology, in addition suitable management practices such as time and amount of fertilizer, irrigation has not been discovered. The different levels of nutrition of maize plants greatly affected the yield and quality [5]. More than a minimum level of nitrogen supply is necessary for $\mathrm{N}$ from vegetative parts to contribute to the formation of seed protein [6]. For development of baby corn research on fertilization, spacing, variety should be prioritized. 
Food insufficiency due to lower area for cultivation demands more production within the same field. Nutrient especially nitrogen is important for increasing productivity. Nitrogen as a constituent of protoplasm and chlorophyll; and is associated with the activity of every living cell. An increased response to applied nitrogen was observed in baby corn by Pandey, et al. [7]. Similarly, overall fertilization the amount of FYM, vermi-compost, urea, DAP, MoP effects the growth and production [8]. The increase in production due to production of higher amount and more efficient translocation of metabolites [9]. This ensures an optimum dose of fertilizer gives maximum production of the baby corn. The cultivation practices should have all aspect of production including efficient fertilization for profitable farming through higher productivity.

The cultivation practices with sound fertilization is a most for increasing the productivity of baby corn and give economic benefits thereby. From the local level research should be conducted for baby corn which aids for commencement of its farming in the country which can uplift the traditional farmer's livelihood. The advancement in farming technology and suitable variety selection with a well-managed nutrition paves the way to commercial farming. "Baby corn" is a profitable crop that allows a diversification of production, aggregation of value, and increased income [7]. This research has focused in the nutrient management and fertilization package which would give optimum yield of baby corn with sound benefit - cost ratios. The effect of different combination of fertilizers in growth parameters and the yield attributing characters are observed.

\section{Materials and Method}

The experiment was carried out at farmer's field of Boudgaun, Sindhupal chowk, Nepal situated at 27043'36.12" N latitude, 85038'32.49"E longitude and altitude of $736 \mathrm{~m}$ above mean sea level. The different treatments are $\mathrm{T}_{1} \rightarrow$ Control, $\mathrm{T}_{2} \rightarrow 100 \%$ inorganic $\mathrm{N}, \mathrm{T}_{3} \rightarrow 75 \%$ inorganic $\mathrm{N}$ and $25 \% \mathrm{FYM}, \mathrm{T}_{4} \rightarrow 75 \%$ inorganic $\mathrm{N}$ and $25 \%$ vermicompost, $\mathrm{T}_{5} \rightarrow 50 \%$ IN and 50\% FYM, $\mathrm{T}_{6} \rightarrow 50 \%$ IN and 25\% FYM, $\mathrm{T}_{7} \rightarrow 25 \%$ inorganic $\mathrm{N}$ and $75 \% \mathrm{FYM}$ and $\mathrm{T}_{8} \rightarrow 25 \%$ IN and $75 \%$ vermicompost. The experiment was laid out in a Randomized Complete Block Design (RCBD) with three replications. Arun-2 Maize variety was planted in three blocks. Each block consisted of eight genotypes randomized and replicated within each block with geometry of PP $40 \mathrm{~cm} \times R R 20 \mathrm{~cm}$. All necessary precautions were taken to maintain uniform plant population in each treatment per replication. All the recommended package of practices (earthing up, weeding, detasseling and irrigation) was followed along with necessary prophylactic plant protection measures to raise a good crop. Observations were recorded and the data was subjected to statistical analysis. Stastistical analysis was done through Microsoft excel 2010, SPSS 16.0 and R 3.1.1 (Figure 1).

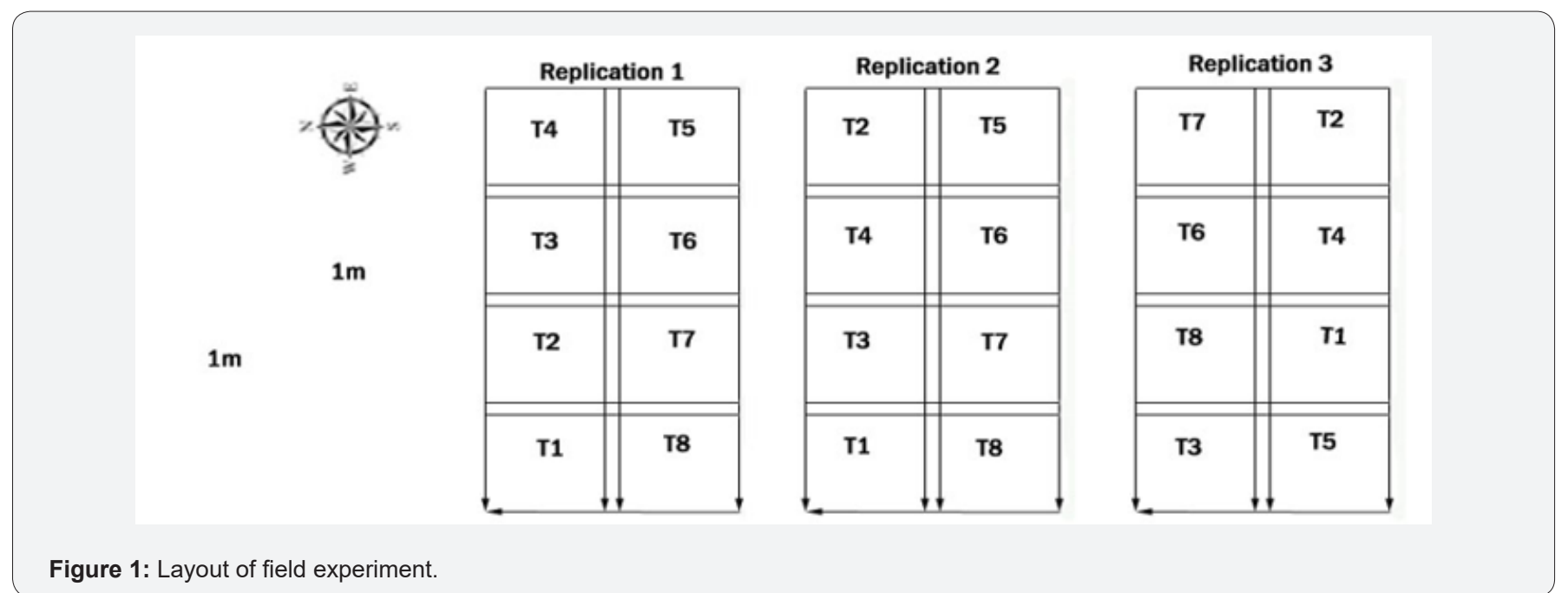

\section{Results and Discussion}

\section{Growth parameters}

Root length: Root length of $\mathrm{T}_{8}$ [25\% inorganic and $75 \%$ vermi-compost] is significantly superior than other treatment (Figure 4.1). Similar result is achieved in [10]. Lee-Joung et al. [11], opined that root length increased with the increase level of vermi-compost. In this research, the maximum root length is observed $36.35 \mathrm{~cm}$ and minimum one is $21.8 \mathrm{~cm}$. Vermi-compost improve the microbial activity, soil health and micronutrient availability [12], Effect of vermi-compost on plant growth and its relationship with soil properties). Chemical reaction (hydrolysis, oxidation, reduction, methylation, alkyl compound detachment) were applied to modify the structure of humic substance isolated from vermicompost. Structural and conformational changes of the humic derivatives were assessed by elemental analyses, size exclusion chromatography (HPSEC), solid state nuclear magnetic resonance (13C CPMAS-NMR), and diffusion order spectroscopy (DOSY-NMR) where as their bioactivity was evaluated by changes in root architecture and proton pump activation in baby corn. Hydrophobic domain can preserve the bioactive molecules such as auxin and organic acid [13]. Vermi-compost have large particulate surface areas that provide many micro sites for microbial activity and for the strong retention of nutrients. Vermi-compost are rich 
in microbial populations and diversity, particularly fungi, bacteria and actinomycetes. Due to their different production processes, compost and vermi-compost might exhibit different physical and chemical features which might influence plant growth and morphology in diverse ways. Other treatment are statistically at par but significantly superior than control plot (Figure 2).

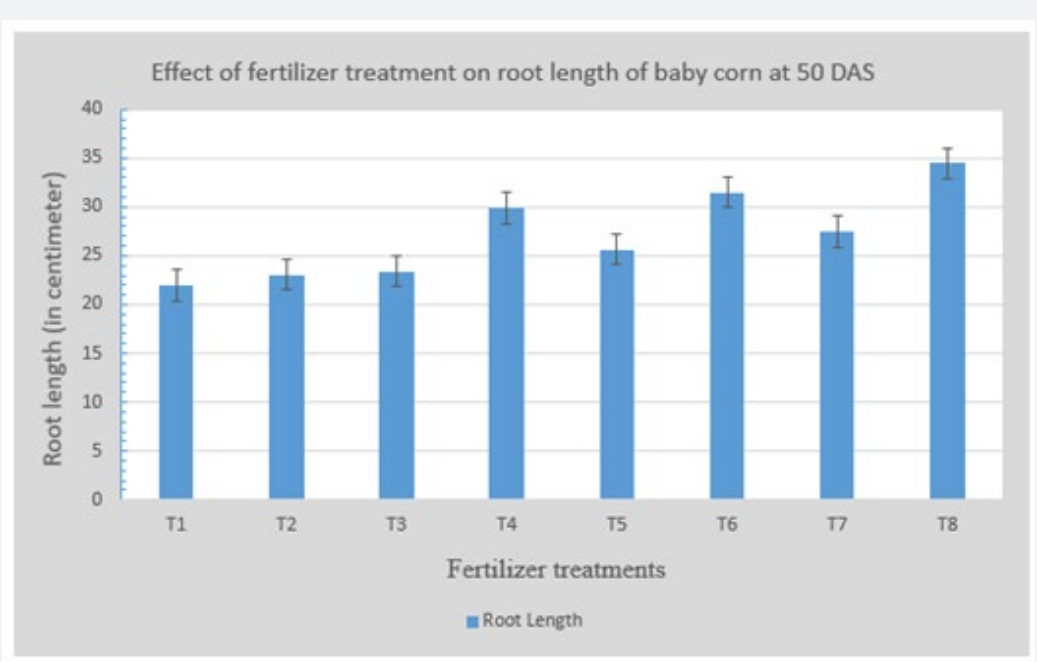

Figure 2 : Effect of fertilizer treatment on root length of baby corn at 50 DAS.

Shoot length: Shoot length of $\mathrm{T}_{8}$ is statistically at par with $\mathrm{T}_{6}$ and $\mathrm{T}_{4}$ but significantly superior thanother treatment. Dadarwal et al. [14] results showed that maximum plant height and dry matter accumulation were recorded under 75\% NPK from 2.25 tons vermi-compost /ha. Similar result is also achieved by [15]. Cristina Lazcano et al. [16], results confirm that the use of organic fertilizers such as vermi-compost has a positive effect on crop growth, yield and quality. The interactions between earthworms and microorganisms can produce significant quantities of plant growth hormones and humic acids which act as plant regulators [12] (Figure 3).

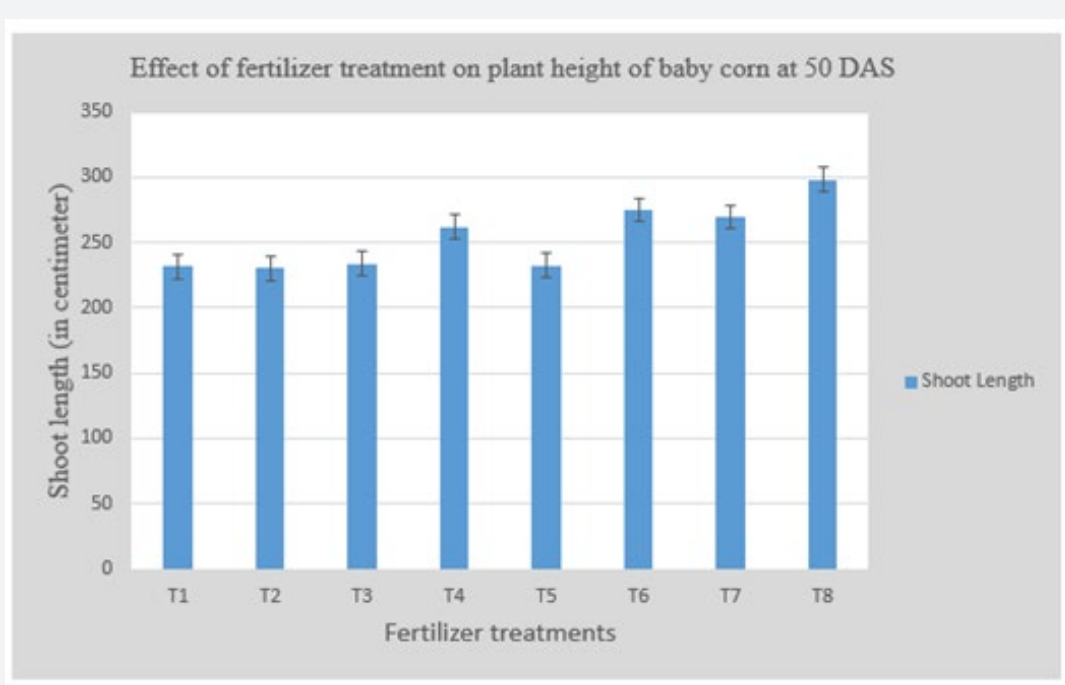

Figure 3: Effect of fertilizer treatment on root length of baby corn at 50 DAS.

Yield attributes: The study revealed that yield component viz. cob length, cob girth, cob weight, corn length, corn girth and corn weight influence significantly with different source of fertilizers. Yield of baby corn without husk in $\mathrm{T}_{8}$ is significantly superior than other treatment (Figure 3). Its due to cob length, cob weight, cob breadth as well as corn length and corn weight are significantly superior than others (Figure 3\&4). The research shows the maximum yield of baby corn is $1833 \mathrm{~kg} / \mathrm{ha}$ and minimum one is
$1571 \mathrm{Kg} /$ ha. Then $\mathrm{T}_{7}, \mathrm{~T}_{5}$ and $\mathrm{T}_{6}$ are statistically at par on the basis of corn yield, cob length and cob weight. And these treatment are statistically superior to $\mathrm{T}_{3}, \mathrm{~T}_{4}, \mathrm{~T}_{2}$ and $\mathrm{T}_{1}$. The present finding are in close agreement with the results obtained by [17]. They reported the application of $75 \%$ NPK from $2.25 \mathrm{t} \mathrm{ha}^{-1}$ vermi-compost + bio fertilizers significantly increased net return, B:C ratio and uptake and available N, P, K status of soil after harvest of Baby corn. Thakur et al. [17] noticed increased number of baby corn cobs 
plant-1 with higher doses of application of vermi-compost. These results corroborate the findings of [18]. FAI [19], recorded the significantly higher growth and yield attributes yield and fodder yield with the application of $75 \%$ of RDF from vermi-compost with bio fertilizer. These are in close conformation with those of Patil \& Bhilare [20]. Nazir khan Mohammadi and RM Pankhaniya, suggest the remarkable improvement in green cob yield by application of vermi-compost [21-26].

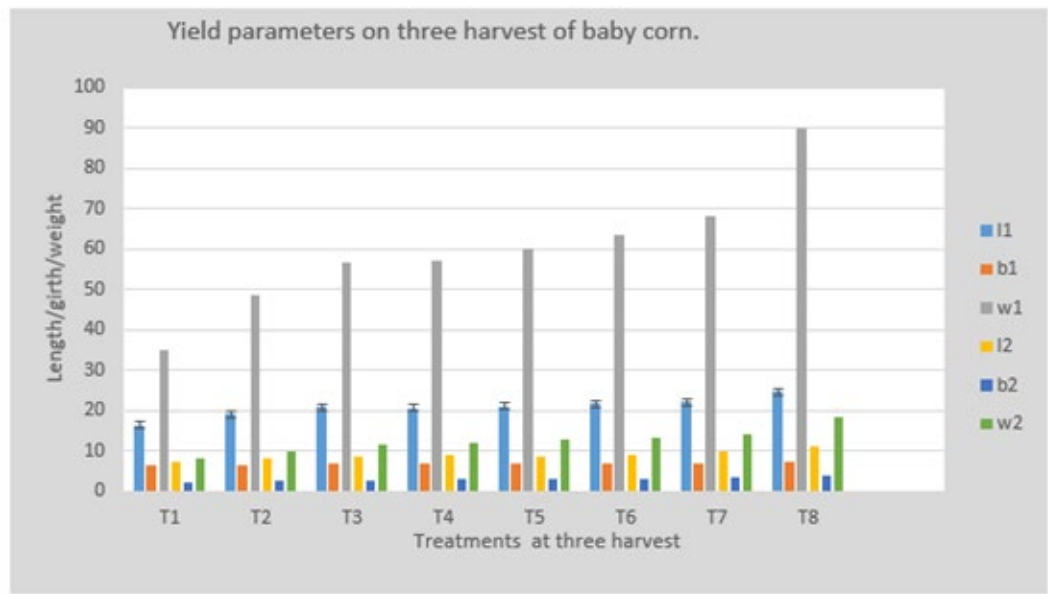

Where $\mathrm{L} 1=\mathrm{cob}$ length, $\mathrm{B} 1=\mathrm{cob}$ girth, $\mathrm{W} 1=\mathrm{cob}$ weight, $\mathrm{L} 2=$ =orn length, $\mathrm{B} 2=$ corn girth, W2=corn weight

Figure 4: Yield parameters on three harvest of baby corn.

\section{Conclusion}

Our present study concluded that fertilizer source $75 \%$ vermicompost (organic) with $25 \%$ chemical fertilizer) is most effective in achieving higher plant performance (growth parameters) and yield attributes (cob length, cob girth and cob weight) for the maize variety ARUN-2 planted in the loamy soil of Boudgaun, Sindhupal chowk.

\section{Acknowledgement}

I owe my gratitude to JAY NEPAL for support, encouragement and provide all resources for this research. I'm very grateful to IAAS, Lamjung Campus and all supportive hands.

\section{References}

1. Ramachandrappa BK, Nanjappa IIV, Shivakumar IIK (2004) Yield and quality of baby corn (Zea mays L.) as influenced by spacing and fertilization levels. Acta Agronomica Hungarica 52(3): 237-243.

2. Galinat WC (1985) Whole ear baby corn, a new way to eat corn. Proc. Northeast Corn Improvement Conf 40:22-27.

3. Demjanova EM, Macak S, Dalovic T, Smatana J, et al. (2009) Effects of tillage systems and crop rotation on weed populations, density, diversity and weed biomass in maize. Agronomy Research 7(2): 785792.

4. Dangwal RL, Singh A, Singh T, Sharma CH (2010) Effect of weeds on the yield of wheat crop in Tehsil Nowshera. Journal of American Science 6(10): 405-407.

5. Kunushi HM, Bandel VA, Nulford FR (1986) Seasonal P uptake of corn under No till and conventional Till. Management Press. pp. 293-296.

6. Venekamps JH, Vries FWTP, Koot JTM (1985) Influence of different levels of nitrogen on nitrogen nutrition and metabolism of maize plants, Zea mays L. Netherlands: Agrobiological Research. pp. 217-226.

7. Pandey AK, Mani VP, Prakash V, Singh RD, Gupta HS (2002) Effect of varieties and plant densities on yield, yield attributes and economics of babycorn (Zea mays). Indian Journal of Agronomy 47(2): 221-226.
8. Singh MK, Singh RN, Singh SP, Yadav MK, Singh VK (2010) Integrated nutrient management for higher yield, quality and profitability of baby corn (Zea mays). Indian Journal of Agronomy 55(2): 100-104.

9. Chillar RK, Kumar A (2006) Growth and yield behaviour of sweet corn (Zea mays L. saccharata) under varying plant population and nitrogen level. In: Extended Summaries of Golden Jubilee National Symposium on conservation Agriculture and Environment, Varanasi, India. pp. 277-278.

10. Ravi Chandra Sharma, Pabitra Banik (2009) Effect of organic and inorganic sources of nutrients on the winter crops-rice cropping system in sub-humid tropics of India. Archives of Agronomy and Soil Science 55(3): 285-294.

11. Lee-Joung K, Park II, Chung J, Kim J (2005) Effect of planting densities and nitrogen levels on the growth characteristics, dry matter yield and nutritive value of corn for silage in alpine areas. Journal of the Korean Society of Grassland Science 25(4): 239-244.

12. Hossein Moradi, Mohammad Fahramand, Alireza Sobhkhizi, Mohammad Adibian, Mohsen Noori, et al. (2014) Effect of vermicompost on plant growth and its relationship with soil properties. IJFAS 3(3): 333-338.

13. LB Dobbss, Luciano Pasqualoto Canella, Fábio Lopes Olivares, Natália Oliveira Aguiar, Lázaro Eustáquio Pereira Peres, et al. (2010) Bioactivity of chemically transferred humic matter from Vermicompost on Plant Root Growth. Journal of agricultural and food chemistry 58(6): 36813688.

14. Dadarwal RS, Jain NK, Singh D (2009) Integrated nutrient management in baby corn (Zea mays). Indian journal of Agricultural Science 79: 1023-102.

15. Vermicompost and Fertilizer Application: Effect on Productivity and Profitability of Baby Corn (Zea Mays L.) and Soil Health Ravi Chandra Sharma \& Pabitra Banik. [2014]

16. Cristina Lazcano et al., (2011) Effect of Vermicompost on Growth, Yield and Quality of Vegetable Crop.

17. Thakur M, Ramesh Kumar, Sandeep Kumar, Bhardwaj ML, Monika Sharma (2014) Genetic Divergence Studies in Lettuce (Lactuca sativa L) Under Protected Conditions in Mid Hills of Himachal Pradesh. IJAIR 3(2): 401-406. 
18. Jinjala VR, Virdia HM, Saravaiya N, Raj AD (2016) Effect of integrated nutrient management on baby corn (Zea mays L.). Agric Sci Digest 36(4): 291-294

19. FAI (1999) Quarterly Bulletin of Statistics. Fertiliser Association of India, New Delhi, India. pp. 1-6.

20. Patil VS, Bhilare RL (2000) Effect of vermicompost prepared from different organic sources on growth and yield of wheat. Journal of Maharashtra Agricultural Universities 25(3): 305-306.

21. Khadtare SV, Patel MV, Jadhav JD, Mokashi DD (2006) Effect of vermicompost on yield and economics of sweet corn. Journal of Soils and Crops 16(2): 401-406.

22. Bindhani A, Barik KC, Garnayak LM, Mahapatra PK (2007) Nitrogen management in Baby corn (Zea mays). Indian Journal of Agronomy 52: 135-138.

\section{This work is licensed under Creative}

Commons Attribution 4.0 License

DOI: 10.19080/ARTOAJ.2018.17.556027
23. Gosavi SP, Bhagat SB (2009) Effect of nitrogen levels and spacing on yield attributes, yield and quality parameters of baby corn (Zea mays). Annals Agricultural Research 30: 125-128.

24. Kotch RS, Murphy JH, Orzolek MD, Ferretti PA (1995) Factors affecting the production of baby corn. J of Veg Crop Prod 1(1): 19-28.

25. Prodhan HS, Bala S, Khoyumthem P (2007) Response to rate of nitrogen and effect of plant density on yield of baby corn. Journal of Inter academicia 11: 265-269.

26. Sarjamei F, Khorasani SK, Nezhad AJ (2014) Effect of planting methods and plant density, on morphological, phenological, yield and yield component of baby corn. Adv Agric Bio 2(1): 20-25.

Your next submission with Juniper Publishers
will reach you the below assets
- Quality Editorial service
- Swift Peer Review
- Reprints availability
- E-prints Service
- Manuscript Podcast for convenient understanding
- Global attainment for your research
- Manuscript accessibility in different formats
( Pdf, E-pub, Full Text, Audio)
- Unceasing customer service
Track the below URL for one-step submission
https://juniperpublishers.com/online-submission.php

